\title{
A participatory Foresight for National Research and Education Networks
}

\author{
Abdul Yaver $^{1}$ - J. M. Sánchez-Torres ${ }^{1}$ - M. A. Amórtegui ${ }^{2}$ - L. Giraldo-Ríos ${ }^{2}$
}

Received: 22 August 2016 / Accepted: 21 November 2016/Published online: 9 December 2016

(C) The Author(s) 2016. This article is published with open access at Springerlink.com

\begin{abstract}
The aim of this paper is to show some results from a Foresight study related to future trends about advanced technology services of National Research and Education Networks (NREN). The approach of this study was conducted by using Foresight methods, which means: a planning process in order to obtain the definition of the exercise scope, the establishment of relevant aspects for asking international experts about the aim of this Foresight study. These experts are directors of several NREN around the world. The main result concludes, among other things, that more network services are being built to provide dark fibber links to users, increasing the flexibility and agility in the delivery of new and better services. It is a trend that will continue and that should be encouraged. Also, collaborations with mobile service providers should be established to offer academically innovative solutions to users. Other results show that there is a potential, which opens the participation of non-university hospitals for remote care in the health sector. This is corroborated in the expert's opinion to qualify for being of high importance for the connectivity of hospitals and clinics. The results of this
\end{abstract}

Abdul Yaver

ayaver@unal.edu.co

J. M. Sánchez-Torres

jmsanchezt@unal.edu.co

M. A. Amórtegui

mikeamortegui@yahoo.com

L. Giraldo-Ríos

lucasgiraldor@gmail.com

1 Universidad Nacional de Colombia, Bogotá, Colombia

2 Red Nacional Académica de Tecnología Avanzada RENATA®, Bogotá, Colombia study are useful for any NREN around the world, but especially they have been used as input for the Colombian NREN.

Keywords National Research and Education Networks . Foresight $\cdot$ Structural analysis $\cdot$ Advanced technology services $\cdot$ Advanced networks

\section{Introduction}

Understanding emerging megatrends and trends has always been a vital issue for industries, for value networks and for the clusters of various industry branches, because big and rapid scientific and technological advances in continuous growth fields have been generated by a clear dynamism within the global competitiveness and by searching for new knowledge frontiers [1].

The development and innovation in telecommunications contribute increasingly to the educational evolution through the use of services and technological tools. The NRENs are physical telecommunication networks of high speed, unique in each country and independent from the commercial internet. They are designed to be an essential infrastructure for the development of education and research in a country, facilitating the reliable, efficient and cost-effective exchange of computer resources through services for communication and collaboration among researchers. Each country decides which groups will benefit from its national research and education network, and many choose to expand connectivity and services to libraries, hospitals, laboratories and governmental organizations [2,3]. The orientation to use telecommunications for educational purposes already generates research works, commercial products and adapted services, and they become a hinge element for collaboration and scientific development of all countries. In order to identify emerging generic 
technologies which probably generate the greatest economic and social benefits, future study processes as Foresight - as a set of systematic attempts to look at in the long term the future of science, technology, economy or society [4] - could resolve the research question: What are the most important trends related to advanced technology services in the NRENs?

Then the aim of this paper is to show some results from a Foresight study related to future trends about advanced technology services of NRENs. ${ }^{1}$ The paper is structured in two main sections, and these are, respectively: a contextualization about NRENs, a Foresight concept, and a Foresight process with elements of the future vision and course of action for the services offered by the NRENs related to criteria discussed in a benchmarking as a previous work and the opinion of experts.

\section{National Research and Education Networks NRENs}

Users in the research and education area do have increasing demand for advanced network services in order to compete on the global stage. These advanced services are often developed and provided by the NRENs, as they are not available in a pervasive way from commercial Internet Service Providers (ISPs) [5].

While provision of connectivity is the major goal, the mission is to create the right environment for science and education communities to facilitate and improve the quality of research and education. This should be realized by unconstrained flow of information, provision of information resources and tools. In addition, the network may be used as a test bed for new network technologies and services. It is fair to say that the test bed feature of the NREN has become slightly sidetracked due to the enormous growth in number of users, diversity and complexity of new services. To attain its goal and mission, the NREN should perform the following activities [6]:

- Provision of network technology which is necessary to interconnect research and academic institutions within the domain of the NREN and to connect to the Internet;

- Identification, development and distribution of network services;

- Analysis and implementation of network technology;

- User assistance and support;

- Education;

- Participation in international network organizations;

\footnotetext{
${ }^{1}$ This paper is part of the final Master work titled: Estudio de Vigilancia $y$ Prospectiva Tecnológica aplicado a Redes Nacionales de Investigación y Educación NRENs, in order to know the current situation of Colombia and the trends in the services of the NRENs and then propose strategic action lines to Colombian NREN; this master work was supported by the National Academic Network of Advanced Technology RENATA ${ }^{\circledR}$ which is the Colombian NREN and the Universidad Nacional de Colombia.
}

- Transfer of network know-how to other institutions and enterprises;

- Contribution to the establishment and implementation of national strategies for the proliferation of the information technology.

NREN is much more than a communication and computing infrastructure. The presence of an NREN indicates the ability of a country to participate in national and international research. In 2013, there were 170 NRENs in 137 countries (out of a total of 206 countries studied). Therefore, about two-thirds of the countries studied had at least one NREN. In 121 countries in 2009 , there were at least one NRENs, but 4 years earlier, in 2005, it is estimated that in 98 countries was at least one NREN [7]. The United States of America (USA) were at the forefront of research and they established the first "national networks" in the service of academia, research and the military community [8].

The NRENs usually work as a hierarchy: on the top there is a national backbone network, beneath there are regional networks, following to metropolitan area networks (MAN), and on the bottom there are networks of individual campuses or institutions. Users can connect directly to a point on the national backbone network or to a regional or metropolitan network. Given the high capacity of the NREN, traffic congestion usually occurs at the level of the local area networks (LAN). Therefore, regardless of how much capacity the core has, the connectivity of researchers in each Institute is limited by their LAN connectivity [9].

As a result of the influence of local conditions there is no unique structure to model accurately all the NRENs.. However, it is clear that most of them have common features. Colombia and many other regions of the world have been based on the European mode (Fig. 1), Europe as one of the world's leaders in research and education networks. It uses a structure of organization of a single NREN by the country with the coordination and collaboration of a continental association, and this has been the key to success [5].

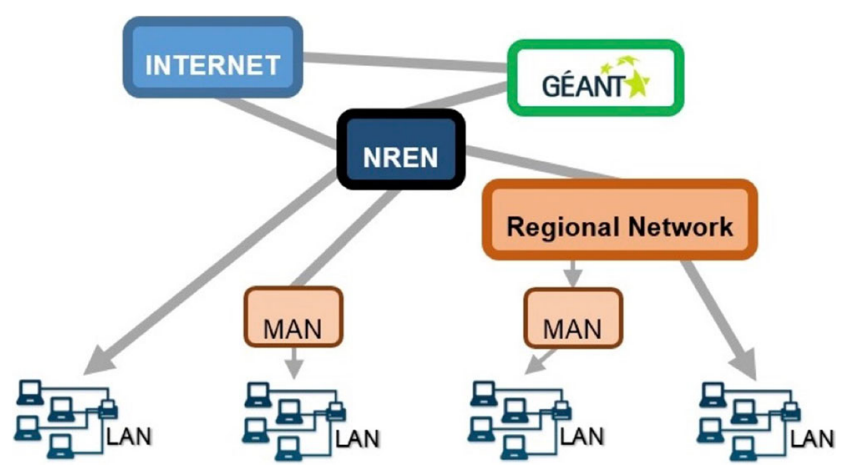

Fig. 1 Structure of the National Research and Education Networks in Europe [10] 


\section{Participatory Foresight}

In the literature, Foresight is often portrayed as a technical and analytical process [11], where the focus lies more on methods, methodologies, or developed systems applied in various contexts (national, regional, sectorial, organizational), depending on the context of a specific Foresight exercise. This approach can be justified regarding Foresight executed on macro levels, where the main aims of Foresight exercises focus rather on the outcomes and not the process itself. This usually takes place when organizational Foresight is considered. It is in business environments where the role of individuals is pivotal to the building of a company's competitive advantage based on Foresight as one of its core competences [12, 13].

Foresight is a set of systematic attempts to look at, in the long term, the future of science, technology, economy and society. It aims to identify emerging generic technologies which probably generate the greatest economic and social benefits [4]. I.e., Foresight studies seek to identify strategic activities for the future development of countries and the technologies associated with them [14].

The potential benefits of the application of Foresight in business practice embrace the following: the ability to spot and interpret environmental changes [15], the enhancement of strategic planning processes [16] and, the increase of innovative capabilities [17].

Foresight is complementary and useful when it comes to face dynamic and complex environments, and when it is required to make strategic decisions as those with high impact, high costs or irreversible effects on the short, medium and long term. For a real impact on organizations Foresight should be systematic, this means, the processes should be repeated over and over again. This discipline requires a long process of learning, where skills are developed thanks to the realization of continues exercises. The articulation of Foresight processes also requires a design according to each organization and situation. It is necessary to adapt the methodological and conceptual diagrams appropriately for each context [18].

Participative Foresight experts are intriguing and captivating, since they capitalize on intellectually virtuous thought processes about the future [19]. The intention is not a prediction nor a falsification; rather, it is about crafting robust images of the future built on the perceptual and creative capacity of the experts. Presumably, we involve domain experts, since they hold explicit and implicit knowledge conducive both to assess the evidence of a present baseline and to elaborate on future images and their trajectories. In doing so, experts attempt to create, analyze, combine and apply both numbers and narratives [20].

Arguably, the integration of qualitative and quantitative information is a major endeavor in Foresight analysis. Both approaches have their assets. Qualitative approaches can have benefits that are not assured by quantitative methods. They can explore relationships and trends where little or no numerical data is available, including shocks and discontinuities. They can more easily incorporate motivations, values, and behavior; they can create similes that capture the imagination of those for whom they are intended. Quantitative approaches, when done properly, provide a rigor, precision, and consistence that comes from their numerical and mathematical underpinnings. Their ontological and epistemological suppositions are made explicit and are, thus, open for critical analysis $[19,20]$.

\section{Methodology}

This is a descriptive study, with a non-experimental design and mixed strategy, based on the Foresight cycle, which has three stages: Pre-Foresight, Foresight and post-Foresight [21]:

Pre-Foresight:

This stage was a benchmarking process where the following factors were compared:

- Financial dependence and governance;

- Connected Institutions;

- Some services provided by several NRENs.

Foresight:

This stage was based on two steps: 1. Expert's consultation and 2. Structural analysis.

Expert's consultation

An on-line survey was performed to explore experts opinions based on the previous results about the future trends of NREN advanced services which are listed on section "Results related to pre-Foresight". It asked about aspects related to importance, materialization, scientific and technological capacity to develop advanced services, among others, and the positive or negative influence of different aspects related to NREN environment.

The set of experts was composed by 16 NRENs directors, which were consulted during March 2016 to June 2016. Table 1 presents the experts consulted and the affiliation for each one.

The main phase was an on-line survey (embedded in the social platform (www.e-encuesta.com) divided into 4 thematic groups, which correspond to categories founded in previous works about the benchmarking related to NRENs and services (competitive intelligence study): 
Table 1 NREN directors consulted

\begin{tabular}{lll}
\hline Director & NREN & Country or Region \\
\hline Alejandro Cecatto & Innovared & Argentina \\
Chris Hancock & AARNet & Australia \\
Nelson Simoes & RNP & Brazil \\
Jim Ghadbane & Canarie & Canada \\
Paola Arellano & Reuna & Chile \\
Juan Pablo Carvallo & CEDIA & Ecuador \\
Tom Fryer & GEANT & Europe \\
Patrick Donath & RENATER & France \\
Hans-Joachim Bungartz & DFN & Germany \\
Enzo Valente & GARR & Italy \\
Florencio Utreras & RedCLARA & Latin America \\
Carlos Casasus & CUDI & Mexico \\
Tomas de Miguel & RedIRIS & Spain \\
Mehmet Mirat Satoglu & Ulakbim & Turkey \\
Paul Feldman & Jisc & United Kingdom \\
Shelton Wabegner & Internet 2 & United States \\
\hline
\end{tabular}

- Personal information: Gender, age, academic level, affiliation, position and knowledge level.

- Trends related to advanced technology services: Importance level, materialization, scientific and technological capacity in your country, applicability, attractive to the development of science and technology in your country, and attractive to market in your country.

- Factors related to development of services in NRENs: Incidence level and governance.

- Open questions: About strategic lines of action for NRENs, dissemination and appropriation of services, and additional recommendations.

Structural analysis

For the purpose of this work, we used the universally accepted intensities for "incidence/importance": high, medium, low or irrelevant, with values of 4, 3, 2 and 1 respectively, and for "governance": high, medium, low or null, with values of $5,3,1$ and 0 respectively, and a Likert scale: Low (1), medium (2) and high (3) for other variables. Thus, you can introduce a certain dynamic in the structural analysis and compare the sensitivity of the results depending on the intensities of considered relations. In addition, the on-line survey was sent to sixteen NRENs managers and eight responses were obtained [22].

\section{Post-Foresight:}

The results of the Foresight stage could be inputs to take decisions on NRENs, and the impact and feedback of these decisions constitute the post-Foresight stage, which are not included in the goals of this paper.

\section{Results}

\section{Results related to pre-Foresight}

One of the most relevant aspects that were found in the benchmarking study among the countries analyzed was their financing by the government. However they are autonomous in choosing their goals and projects, as shown in Table 2.

Another important aspect is that the largest number of connected institutions are universities followed by research institutes, non-university higher education centers (with Mexico and United Kingdom as main contributors). On the contrary, organizations such as libraries, museums, hospitals, elementary and high schools and government entities represent less than $20 \%$ of the institutions connected.

Table 3 shows the number and percentage of institutions connected to the different analyzed NRENs. The cell's color represents the range of percentage of institutions or entities connected compared to the total number existing in the country. If there is no specific numerical quantity of institutions or entities connected, the abbreviation "n.a." is displayed to indicate that numeric data does not exist.

Brazil, Canada, Colombia and Spain reached a precedent regarding the opportunity to open the participation of non-university hospitals for remote care in the health area. This is corroborated in the expert's opinion as being classified of high importance for the connectivity for hospitals and clinics.

Table 4 shows some examples of the services provided by the different NRENs that were compared, identifying with dark green services with a strong trend, and light green services with a slight tendency. There were more services compared in this study but Table 4 shows the results specifically related to connectivity services, cloud services, security services, and videoconferencing and communications services.

The trends obtained after benchmarking and prioritization process by the $\mathrm{CEO}$ and academic manager of the Colombian NREN were:

1. Develop innovative applications which will be tested in academic institutions, companies or pilot projects.

2. Provide services for managing domains.

3. Provide services for Identity Federation.

4. Provide services for issuing digital certificates.

5. Provide services for meetings and calendar within communities.

6. Finance together allies NREN innovation projects through public calls.

7. Provide services for development of scientific and academic processes.

8. Establish partnerships with mobile service providers to offer academic innovative solutions.

9. Provide users with dark fiber links. 
Table 2 Financial dependence and governance of the NRENs [23, 24]

\begin{tabular}{|c|c|c|c|c|c|c|c|c|c|c|c|c|}
\hline \multirow[t]{2}{*}{ Type } & \multirow{2}{*}{$\begin{array}{l}\text { Region } \\
\text { Country }\end{array}$} & \multicolumn{3}{|l|}{ Europe } & \multicolumn{2}{|c|}{ North America } & \multicolumn{2}{|c|}{ Asia/Oceania } & \multicolumn{4}{|c|}{ Latin America } \\
\hline & & Germany & Spain & United Kingdom & USA & Canada & Australia & Turkey & Brazil & Chile & Mexico & Colombia \\
\hline \multicolumn{13}{|c|}{ Financing } \\
\hline \multicolumn{2}{|c|}{ Total } & & $\checkmark$ & & $\checkmark$ & & & $\checkmark$ & $\checkmark$ & & & \\
\hline \multicolumn{2}{|c|}{ Partial } & & & $\checkmark$ & & $\checkmark$ & & & & & & $\checkmark$ \\
\hline \multicolumn{2}{|c|}{ None } & $\checkmark$ & & & & & $\checkmark$ & & & $\checkmark$ & $\checkmark$ & \\
\hline \multicolumn{13}{|c|}{ Governance } \\
\hline \multicolumn{2}{|c|}{ Autonomous } & $\checkmark$ & & $\checkmark$ & $\checkmark$ & $\checkmark$ & $\checkmark$ & & $\checkmark$ & $\checkmark$ & $\checkmark$ & $\checkmark$ \\
\hline \multicolumn{2}{|c|}{ Dependent } & & $\checkmark$ & & & & & $\checkmark$ & & & & \\
\hline
\end{tabular}

10. Update or reach a capacity in the order of $100 \mathrm{~Gb} / \mathrm{s}$ or higher.

11. Provide services for monitoring network performance to optimize and measure traffic and connections.

12. Provide services for remote applications support.

13. Provide configuration services with Network Time Protocol (NTP) to synchronize.

14. Provide services for Network operations center (NOC).

15. Connect libraries, museums and cultural centers.

16. Connect hospitals and clinics.

17. Connect governmental entities.

18. Provide Cloud storage solutions.

19. Offer services for storing audiovisual content.

20. Provide services for web filtering and security of emails and blacklists.
21. Provide security services for architecture.

22. Provide services for the provision of mobile communications.

23. Provide services for the distribution of multicast content via lightpath.

24. Provide signal transmission services IPTV, multicast, streaming.

\section{Results related to Foresight}

A total of 8 NRENs managers (over 40 years old) took part in this study, 1 female and 7 males. $64.3 \%$ of the experts consulted expressed to have a high knowledge on issues related to advanced technology services offered by NRENs, and

Table 3 Number and percentage of entities connected to NREN from each country [23, 24]

\begin{tabular}{|c|c|c|c|c|c|c|c|c|c|}
\hline Region & Country & Universities & $\begin{array}{l}\text { Higher } \\
\text { education } \\
\text { centers }\end{array}$ & $\begin{array}{l}\text { Research } \\
\text { institutes }\end{array}$ & $\begin{array}{l}\text { High } \\
\text { schools }\end{array}$ & $\begin{array}{l}\text { Primary } \\
\text { schools }\end{array}$ & $\begin{array}{l}\text { libraries, } \\
\text { museums, } \\
\text { cultural } \\
\text { centers }\end{array}$ & Hospitals & $\begin{array}{l}\text { Government } \\
\text { entities }\end{array}$ \\
\hline \multirow{3}{*}{ Europe } & Germany & n.a. & n.a. & n.a. & n.a. & n.a. & n.a. & n.a. & n.a. \\
\hline & Spain & 93 & 6 & 199 & n.a. & n.a. & 48 & 57 & 32 \\
\hline & $\begin{array}{c}\text { United } \\
\text { Kingdom }\end{array}$ & 167 & 428 & 36 & n.a. & n.a. & 8 & n.a. & 6 \\
\hline \multirow{2}{*}{$\begin{array}{l}\text { North } \\
\text { America }\end{array}$} & USA & n.a. & n.a. & n.a. & n.a. & n.a. & n.a. & n.a. & n.a. \\
\hline & Canada & 190 & n.a. & n.a. & n.a. & 2000 & 24 & 62 & 127 \\
\hline \multirow{2}{*}{$\begin{array}{c}\text { Asia/ } \\
\text { Ocenia }\end{array}$} & Australia & 58 & 16 & 28 & 61 & 80 & 8 & 6 & 8 \\
\hline & Turkey & 162 & n.a. & 16 & n.a. & n.a. & 1 & n.a. & 13 \\
\hline \multirow{4}{*}{$\begin{array}{l}\text { Latin } \\
\text { America }\end{array}$} & Brazil & 826 & 3 & 167 & 11 & n.a. & 154 & 53 & 77 \\
\hline & Chile & 17 & n.a. & 4 & n.a. & n.a. & n.a. & n.a. & 3 \\
\hline & Mexico & 111 & 103 & 28 & n.a. & n.a. & 2 & 5 & 18 \\
\hline & Colombia & 142 & n.a. & 6 & n.a. & n.a. & 3 & 14 & 4 \\
\hline \multicolumn{2}{|c|}{$>80 \%$} & $40-60 \%$ & \multicolumn{2}{|c|}{$<20 \%$} & \multirow[b]{2}{*}{ n.a. } & \multirow{2}{*}{\multicolumn{2}{|c|}{ Without numeric data }} & & \\
\hline \multicolumn{2}{|c|}{$60-80 \%$} & $20-40 \%$ & \multicolumn{2}{|c|}{ Without percentage data } & & & & & \\
\hline
\end{tabular}


Table 4 Trends on some services provided by selected NRENs

\begin{tabular}{|c|c|c|c|c|c|c|c|c|c|c|c|c|}
\hline \multirow[b]{2}{*}{ classification } & \multirow[b]{2}{*}{ services } & \multicolumn{3}{|c|}{ europe } & \multicolumn{2}{|c|}{$\begin{array}{c}\text { North } \\
\text { America }\end{array}$} & \multicolumn{2}{|c|}{ Asia/Oceania } & \multicolumn{4}{|c|}{ Latin America } \\
\hline & & Germany & Spain & UK & USA & Canada & Australia & Turkey & Brazil & Chile & Mexico & Colombia \\
\hline \multirow{5}{*}{$\begin{array}{l}\text { Connectivity } \\
\text { services }\end{array}$} & Connectivity & $\checkmark$ & $\checkmark$ & $\checkmark$ & $\checkmark$ & $\checkmark$ & $\checkmark$ & $\checkmark$ & $\checkmark$ & $\checkmark$ & $\checkmark$ & $\checkmark$ \\
\hline & Remote support & $\checkmark$ & $\checkmark$ & $\checkmark$ & & & & & & & & \\
\hline & Domain management & $\checkmark$ & $\checkmark$ & $\checkmark$ & & & & & & & & \\
\hline & Network time services & & $\checkmark$ & $\checkmark$ & & & & & & & & \\
\hline & Eduroam & $\checkmark$ & $\checkmark$ & $\checkmark$ & $\checkmark$ & $\checkmark$ & $\checkmark$ & $\checkmark$ & $\checkmark$ & $\checkmark$ & $\checkmark$ & $\checkmark$ \\
\hline \multirow{5}{*}{$\begin{array}{l}\text { Cloud } \\
\text { Services }\end{array}$} & Platform for interaction & $\checkmark$ & $\checkmark$ & $\checkmark$ & $\checkmark$ & & $\checkmark$ & & $\checkmark$ & $\checkmark$ & $\checkmark$ & $\checkmark$ \\
\hline & Big data \& analytics & & & & & & & & & & & \\
\hline & File sharing & $\checkmark$ & $\checkmark$ & $\checkmark$ & $\checkmark$ & $\checkmark$ & $\checkmark$ & $\checkmark$ & $\checkmark$ & $\checkmark$ & $\checkmark$ & $\checkmark$ \\
\hline & Cloud storage & $\checkmark$ & $\checkmark$ & $\checkmark$ & $\checkmark$ & $\checkmark$ & $\checkmark$ & $\checkmark$ & $\checkmark$ & $\checkmark$ & $\checkmark$ & $\checkmark$ \\
\hline & $\begin{array}{l}\text { Deepfield analytics service } \\
\text { (Cloud monitoring) }\end{array}$ & & & & $\checkmark$ & & & & & & & \\
\hline \multirow{3}{*}{ Security services } & Web filtering & & & $\checkmark$ & & & & & & & & \\
\hline & Network security & $\checkmark$ & $\checkmark$ & $\checkmark$ & & & & $\checkmark$ & $\checkmark$ & & $\checkmark$ & \\
\hline & $\begin{array}{l}\text { Security for e-mails and } \\
\text { blacklists }\end{array}$ & $\checkmark$ & $\checkmark$ & $\checkmark$ & & & & & $\checkmark$ & & $\checkmark$ & \\
\hline \multirow{6}{*}{$\begin{array}{c}\text { Videoconference } \\
\text { and } \\
\text { communications } \\
\ldots\end{array}$} & Videoconference & $\checkmark$ & $\checkmark$ & $\checkmark$ & $\checkmark$ & $\checkmark$ & $\checkmark$ & $\checkmark$ & $\checkmark$ & $\checkmark$ & $\checkmark$ & $\checkmark$ \\
\hline & SMS messaging & $\checkmark$ & & 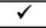 & & & & & & & & \\
\hline & IP telephony & $\checkmark$ & & $\checkmark$ & & & $\checkmark$ & & $\checkmark$ & $\checkmark$ & & $\checkmark$ \\
\hline & $\begin{array}{l}\text { Providing mobile } \\
\text { communications }\end{array}$ & $\checkmark$ & & & & & & & & & & \\
\hline & Web conference & $\checkmark$ & & & $\checkmark$ & $\checkmark$ & $\checkmark$ & $\checkmark$ & $\checkmark$ & $\checkmark$ & $\checkmark$ & $\checkmark$ \\
\hline & Streaming... & $\checkmark$ & & $\checkmark$ & $\checkmark$ & & $\checkmark$ & $\checkmark$ & $\checkmark$ & $\checkmark$ & $\checkmark$ & $\checkmark$ \\
\hline
\end{tabular}

$35.7 \%$ expressed to have a medium knowledge. Table 5 shows the information about experts who answered the survey.

Figure 2 shows the importance that experts gave to each topic related to advanced technology services, which areproposed as trends and the expected materialization.

The experts considered these trends as the most important and urgent ones to implement:
- Development of innovative applications, which will be tested in academic institutions, companies or pilot projects;

- Providing services for the Identity Federation;

- Financing of innovation projects through public calls along allies of the NREN;

- Reaching a capacity of $100 \mathrm{~Gb} / \mathrm{s}$ or higher;

Table 5 Information about experts who answer the survey

\begin{tabular}{lll}
\hline \# Country & NREN & Academic formation \\
\hline 1 Australia & AARNet & $\begin{array}{l}\text { MBA, Business - Australian Graduate School } \\
\text { of Management. }\end{array}$ \\
2 Brazil & RNP & $\begin{array}{l}\text { Computing Engineering - Pontifícia Universidade } \\
\text { Católica do Rio de Janeiro }\end{array}$ \\
3 Chile & Reuna & $\begin{array}{l}\text { MBA - Universidad de Chile. Natural Resources } \\
\text { Engineering - Universidad Católica de Valparaiso }\end{array}$
\end{tabular}

Experience

Human resources chief, Seven Network. Human resources chief, Vodafone Australia. Managing Director, Optus. $\mathrm{CEO}$ at $A A R N e t$.

Experience in the area of computer science, with an emphasis on $\mathrm{r} \& \mathrm{~d}$ and computer networks. CEO at RNP.

It has coordinated and contributed to the development of important initiatives and projects in the areas of telecommunications, education and technology for various areas of scientific and academic work. CEO et REUNA for 17 years.

4 Ecuador CEDIA Systems Engineering- Universidad de Cuenca. Master Consultant and computer Manager in the private sector. in Systems Networks, Advanced Services Dissemination and Telecommunication management - Universitat Politècnica de Catalunya. PhD. Software Engineering Universitat Politècnica de Catalunya

5 Spain RedIRIS PhD Telecommunications Engineering Universidad Politécnica de Madrid

6 Europe GEANT Modern languages and Linguistics - University of Essex

7 Latin America RedCLARA Degree in Mathematics and Engineering Universidad de Chile. PhD Engineering University of Grenoble

8 Mexico CUDI Master of Business Administration - Harvard Business School
Director national of management technology at

Universidad del Pacífico. University professor. CEO at CEDIA.

University professor. Director de RedIRIS.

Extensive experience as commercial director. International relations chief at GEANT.

University professor. CEO at RedCLARA.

President at Consejo Directivo en Consorcio para el Interncambio de Tráfico de Internet. CEO at CUDI. 
Fig. 2 Importance that experts give to each topic related to advanced technology services and expected materialization (Source: authors)

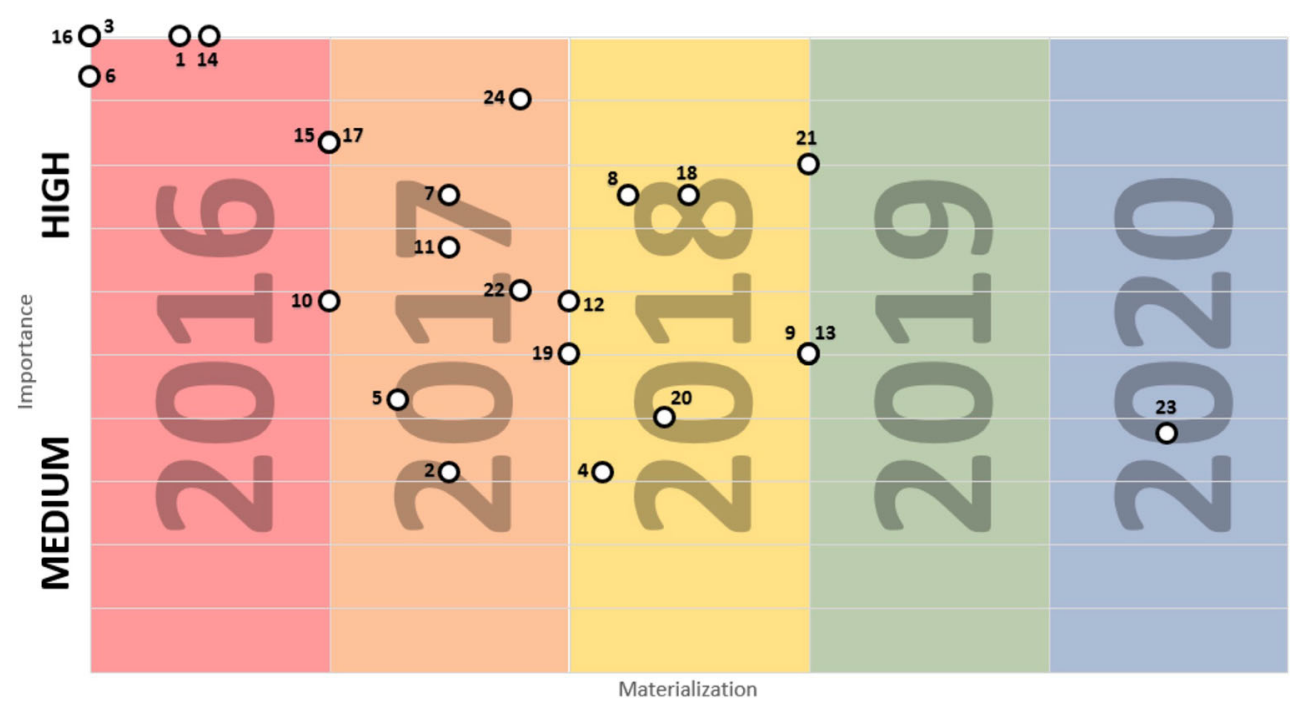

- $\quad$ Providing services for Network operations center (NOC);

- Connecting libraries, museums and cultural centers;

- Connecting hospitals and clinics and connecting governmental entities.

Brazil along with Colombia are making a precedent in Latin America about the connectivity of institutions different than universities or research centers. But as suggested by the experts, NRENs should develop innovative applications which will be tested in academic institutions, companies or pilot projects. As this is just a collaboration between members, it does not imply high cost of implementation.

Figure 3 shows the importance that experts give to each topic related to advanced technology services which are proposed as trends. It also shows the attractiveness to the market in their country considered by them.

These topics were classified again, as shown in Fig. 4, to expose the position of trends as attractive to the development of science and technology in their country depending on its scientific and technological capacity.

Firstly, these opinions showed that although there are trends like providing services for managing domains, providing services for issuing digital certificates, or providing services for meetings and calendars within communities. These can be covered through the scientific and technological capacities and they are not considered important. So efforts in developing them should not be wasted.

Similarly, opinions sensed that there are services like providing services for web filtering and security of emails and blacklists that although it would be very attractive for the market and users, in fact is not important for the development of the academic and scientific communities, and therefore no primary target of the NRENs.

Trends in red color are important, attractive for the development of science and technology, attractive for the market and users, and possess high scientific and technological
Fig. 3 Importance that experts give to each topic related to advanced technology services and the attractiveness to the market in their country. (Source: authors)

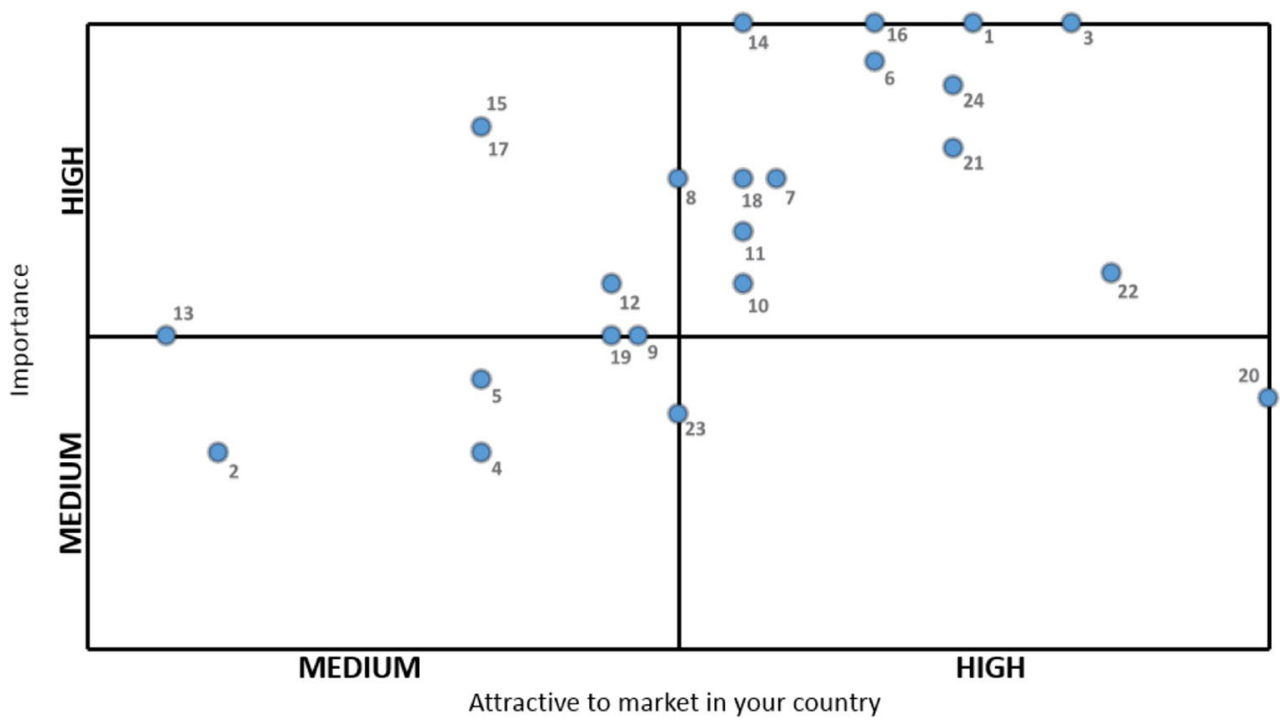


Fig. 4 Importance that experts give to each topic related to advanced technology services and the attractiveness to the market in their country. Attractive to development of science and technology in their country depending on scientific and technological capacities (Source: authors)

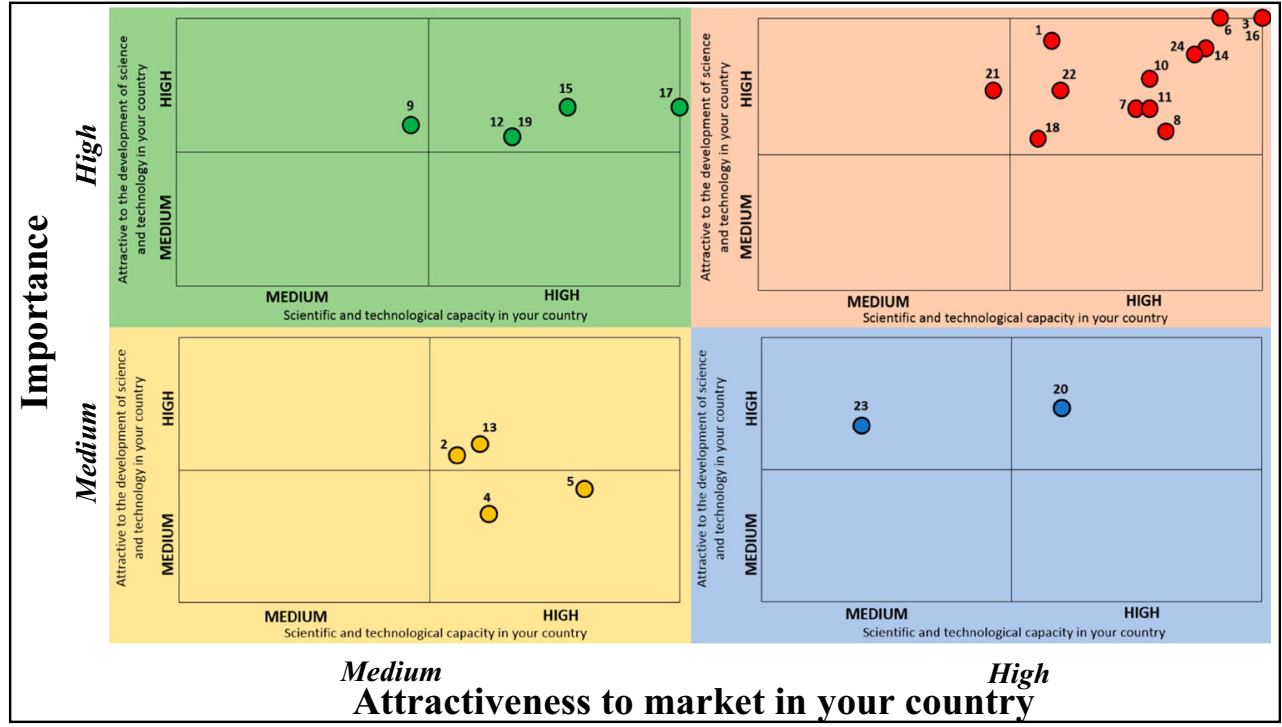

3. Legislation - Regulations (Public policy development);

4. Implementation costs;

5. Support of Government entities;

6. Support and partnership with the private sector;

7. Level of training of human resources in the country;

8. Access costs for institutions.

The expert panel considered the development of scientific and technological capabilities as a very important aspect for the development and provision of services of the NRENs, i.e. it demonstrated the importance of the presence of departments for research as well as development and innovation in institutions. Therefore, the NRENs should ensure that the community is kept up to date with the evolution of networks through the organization of workshops and conferences, and the participants in these events should be members of institutional management, and the information technology staff.

1. Development of scientific and technological capabilities;

2. Community Integration;

Fig. 5 Incidence that the expert panel gives to different aspects that may influence on optimal provision of NREN advanced technology services (Source: authors)

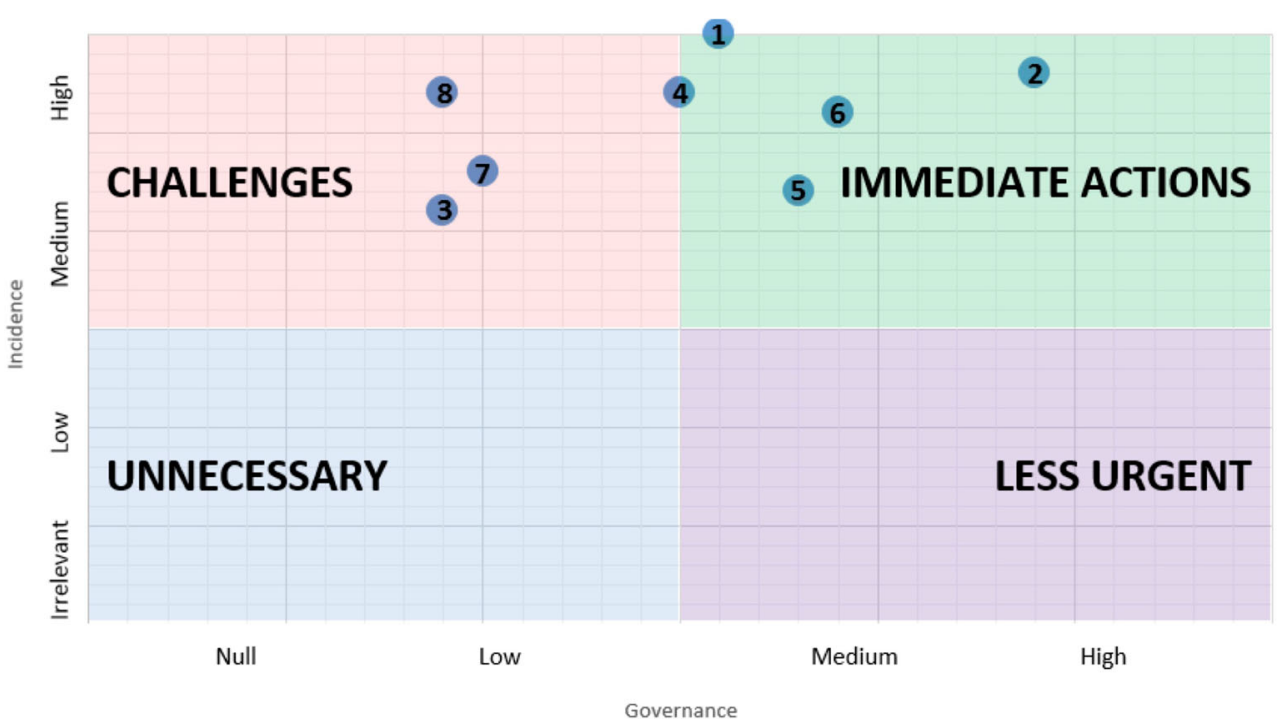


On the one hand, the NRENs should take immediate action on handling issues as development of scientific and technological capabilities, community integration, support of government entities. They also should support and partnership with the private sector, that are high impact and high governance, so it can help in the short-term improvement of the quality of services. On the other hand, NRENs should establish partnerships or evolve in relations with stakeholders to improve aspects such as legislation or regulations (Public policy development), implementation costs, level of training of human resources in the country, access costs for institutions, which has a limited governance, but these are necessary to improve the quality of services.

Some of the suggestions expressed by the experts relate to the strategic management within the NRENS. They should ensure that members are punctual in payment of their assessed contributions. The suggestions should also help to consult the academic community in its needs to add value services to the customer and to establish more channels of communication between the institutions and the NRENS. This should allow to disseminate and to appropriate services, to develop marketing plans and to constantly improve the ease of use of the services.

\section{Conclusions}

In this section we are showing a general conclusion for NRENs. However there are some points that would be useful for NREN, which belongs to developing countries such as Colombian NREN.

By using Foresight and competitive intelligence as a systematic process, NRENs obtain inputs for taking into account in their strategic business planning and service delivery.

Thus, as the benchmarking remarked that the financial government supports the NRENs, this results in dependence, which can be a risk in the long-term. In spite of the dependence there is autonomous governance, which generally involves decentralizing decision-making to NRENS, enabling them to make a greater number of decisions about their operation and work.

Also the benchmarking showed countries such as Brazil, Canada, Colombia and Spain, reaching a precedent with respect to the potential of the participation of non-university hospitals for remote care in the health sector. This is corroborated in the expert's opinion to qualify for being of high importance for the connectivity for hospitals and clinics. In the Colombian case as a developing country, for instance, these hospitals have implemented tele-medicine services for attending vulnerable population in far and poor areas, showing benefits of using NREN's infrastructure.

Regarding to services provided by NRENs, it is observed that the least common connectivity services such as remote support, domain management, and network time services, are provided by less than four NRENs. Also, it shows that rather common connectivity services include dark fiber for linking users are increasing the flexibility and agility in delivering new and better services. Also security services are part of rather common services that are offered as a way to protect the data to increase NREN's users productivity by reducing wasted time and resources.

More of National Science, Technology and Innovation system capabilities and more demand of services means a great effort, on one side, for maintaining a modern infrastructure and on other side for developing skills on the end-users and on the technical administrators of the NRENs.

Technological advances have revolutionized molecular biology through technological infrastructure through offering computer programs to biologists, doctors and other professionals in order to research the protein composition of the tropical diseases. In this case the prospective exercise sheds some lights on what kind of services must be strengthened or developed by the European NREN, not only in an endemic work, if not with a perspective to provide support to emerging countries.

One of the fields of application arises from the need for capacity of distributed computing, applied to the understanding of tropical diseases. One of this examples is the Universitat Rovira i Virgil (URV) in which 12 universities and research centers of nine countries are involved. The work is based on analyzes of samples taken of the breath, easy to obtain and minimally invasive. According to Radu Ionescu [25], during the first year of the project samples in Colombia (dengue) will be taken in Tunisia (hydatid disease and leishmaniasis) and Poland (as an example of European country where they are not usual). So when factors such as the location of populations are analyzed and the transmission of high volumes of data in real time is needed, a reliable connection across Europe using capabilities and computing services distributed over the NREN services of those countries is justified. One of the initiatives which aimed to meet this need was the project $\mathrm{E}$ science grid facility for Europe and Latin America - EELA, which ended in 2008 . The continuity should be given through the EELA 2 project, approved by the 7th Framework Program of the European Union and completed in 2010. This should provide users of infrastructure grid stable and well support, based on 16 Resource Centers (RCs) totaling more than 730 CPU cores and 60 terabytes of storage, according to publication on the website of RedClara [26].

As shown by the findings and considering scenarios in short and medium term, distance education (e-education) has greater relevance. While this model is highly developed in Europe, where universities offer a wide and diverse type of courses, a greater willingness to these is required in the infrastructure of the NREN or development of common platforms where the whole continent can develop different forms of distance education, such as $100 \%$ online courses, blended 
learning developments, m-learning, MOOC and augmented reality. Furthermore, there is the possibility of being accessed using NREN interconnections with developing countries such as Colombia, where the virtual university education grew by $500 \%$ in the last 5 years [27].

On the other hand, as mentioned in the 2008 report, conducted by RedClara: "Today, beyond the importance of using advanced networks to bring educational processes towards the most deprived and isolated areas, matter crossing horizontally to Latin America, it is the joint and the study of technologies and applications for the development and implementation of Learning Objects" [28]. In this regard, the recommendation is to provide or develop jointly with Colombia platforms, repositories and software development for creating learning objects, together with researchers, professors and users in Europe and Colombia innovations.

Our Foresight study has concluded that establishing and strengthening relationships with commercial and business partners is definitely attractive and important for the development of the abilities of science and technology in a country. A study conducted by Ipsos Public Affairs gathered information from more than 1500 decision makers surveyed in the United States and 10 European countries, showing that $65 \%$ of these senior managers consider the contribution of Data Analytics as important in their companies, opining that these processes generate jobs and help businesses to improve the response to the needs of their customers. Therefore, they should offer services as tools for data analysis, and close relations with academic and scientific communities within countries. This will allow that NRENs, through alliances with companies from different sectors, contribute to business innovation helping national and multinational companies to improve their performance, using data to find ideas, answers, and innovative solutions to problems large and small, with its consequential long-term benefits on the economic for the country and the continent where they are [29].

A study conducted by IBM and the Said Business School of Oxford University about "using Big Data in the real-world" [30] shows that most of the companies ( $71 \%$ of those surveyed) are in the early stages of development of Big Data initiatives. It also shows processes that create an opportunity for companies to gain a competitive advantage in today's digitized market. None of the analyzed NRENs in our Foresight study deploy services related with Big Data. Then the NRENs have an opportunity to link their activities with partners to innovate on processes of business if they focus their contribution $o$ aspects as:

- Initial efforts to obtain results client-focused.

- Develop a Big Data plan for enterprise-wide.

- Begin with existing data to achieve short-term results.

- Develop analytical capabilities based on business priorities.
- Create a case of business based on measurable results.

In this way the NREN would help companies to advance in their efforts of Big Data and get the maximum business value, innovating to obtain beforehand a more complete view of preferences and demands of customers.

Acknowledgements The authors express thanks to Red Nacional Académica de Tecnología Avanzada RENATA®, and Universidad Nacional de Colombia and its research group Grupo de Investigación en Gestión y Organizaciones GRIEGO.

Open Access This article is distributed under the terms of the Creative Commons Attribution 4.0 International License (http:// creativecommons.org/licenses/by/4.0/), which permits unrestricted use, distribution, and reproduction in any medium, provided you give appropriate credit to the original author(s) and the source, provide a link to the Creative Commons license, and indicate if changes were made.

\section{References}

1. Olsmats C, Kaivo-oja J (2014) European packaging industry foresight study - identifying global drivers and driven packaging industry implications of the global megatrends. Eur J Futur Res 2(1). doi:10.1007/s40309-014-0039-4

2. Hashem M M A (2012) Understanding the Research and Education Networks. Teletech 26-30

3. Tusubira F F (2011) Creating the Human and Infrastructure Research and Education Networks in Africa, UbuntuNet Alliiance. https://tnc2009.terena.org/core/getfiled3d9.pdf?file id $=412$. Accessed 15 Nov 2016

4. Fernández L Á (2003) La economía del conocimiento según la OCDE

5. Dyer J (2009) The case for National Research and Education Networks (NRENs). Terena. https://www.terena. org/publications/files/20090127-case-for-nrens.pdf. Accessed 15 Nov 2016

6. Popov O (2003) Building a National Research and Education Network. Creat Innov Netw Manag 13-26

7. ITU (2014) Partnership on measuring ICT for development. Final WISIS targets review. Achievements, challenges and the way forward. Geneva, Switzerland

8. Corbin RA (1991) The development of the national research and education network. Inf Technol Libr 10(3):212-220

9. Seth D P S (2006) A report on National Knowledge Network. New Delhi

10. Olesen D, Arak R, Bressler P, Cavalli V, Davies D, Dyer J et al (2008) Innovation, integration and deployment. Challenges for European research and education networking. Terena. https://www.terena.org/publications/files/EARNEST-SummaryReport.pdf. Accessed 15 Nov 2016

11. Cunha MP, Palma P, da Costa NG (2006) Fear of foresight: knowledge and ignorance in organizational foresight. Futures 38(8):942-955

12. Vecchiato R, Roveda C (2010) Strategic foresight in corporate organizations: handling the effect and response uncertainty of technology and social drivers of change. Technol Forecast Soc Change 77(9):1527-1539

13. Kononiuk A, Sacio-Szymańska A (2015) Assessing the maturity level of foresight in Polish companies - a regional perspective. Eur J Futur Res 3(1). doi:10.1007/s40309-015-0082-9 
14. Medina J, Ortegón E (2006) Manual de prospectiva y decisión estratégica: bases teóricas e instrumentos para América Latina y el Caribe. Insituto Latinoam y del Caribe Plani. Económica y Soc 438

15. Tsoukas H, Sheperd J (2004) Coping with the future: developing organizational foresightfulness - introduction. Futures 36:137-144

16. Roney CW (2010) Intersections of strategic planning and futures studies: methodological complementarities. J Futures Stud 15(2): $71-100$

17. Rohrbeck R (2011) Corporate foresight: its three roles in enhancing the innovation capacity of a firm. Technol Forecast Soc Change 78(2):231-243

18. Medina Vásquez J, Sánchez Torres J M (2008) Sinergia entre la Prospectiva Tecnológica y la Vigilancia Tecnológica e Inteligencia Competitiva. Colciencia

19. Karlsen JE, Karlsen H (2007) Expert groups as production units for shared knowledge in energy foresights. Foresight 9(1):37-49

20. Karlsen J E (2014) Design and application for a replicable foresight methodology bridging quantitative and qualitative expert data. Eur J Futur Res 2(1). doi:10.1007/s40309-014-0040-y

21. Canongia C, Santos DM, Santos MM, Zackiewicz M (2004) Foresight, inteligência competitiva e gestão do conhecimento: instrumentos para a gestão da inovação. Gestão \& Produção 11(2):231-238
22. Alfonso Ramón Chung Pinzás (2013) Matriz IGO. https://ramonchung.wordpress.com/2013/02/28/matriz-igo/. Accessed 15 Nov 2016

23. TERENA (2014) GÉANT Association Compendium of National Research and Education Networks in Europe. Amsterdam

24. RedClara (2015) Compendio RedCLARA de Redes Nacionales de Investigación y Educación Latinoamericanas 2013

25. Virgil U R (2015) Una nueva tecnología diagnosticará enfermedades tropicales a través del aliento. http://noticias. universia.es/ciencia-nn-tt/noticia/2015/02/18/1120141/nuevatecnologia-diagnosticara-enfermedades-tropicales-traves-aliento. html. Accessed 15 Nov 2016

26. RedClara (2011) Proyecto Eela2. Coop. Latinomericana para Redes Av

27. El Tiempo (2015) En un 500\% creció demanda de educación superior virtual en Colombia. Periódico El Tiempo 36-45

28. CEPAL (2008) Meta 10 eLAC2007: RedCLARA y las Redes Nacionales de Investigación y Educación

29. Alliance T S (2014) Casi dos tercios de las empresas europeas consideran a Data Analytics como fundamental

30. Value B (2012) Analytics: el uso de big data en el mundo rea 